\title{
STUDI KOMPARASI IMPLEMENTASI KURIKULUM PADA \\ PEMBELAJARAN AKSELERASI DAN PEMBELAJARAN REGULER (Kajian pada Kelas XI CI+BI IPA dan Kelas XI IPA di SMAN 1 Padang)
}

\author{
Yessi Rifmasari \\ STKIP Adzkia Padang \\ rifmasari.yessi@yahoo.com
}

\begin{abstract}
The study was based on differences in the characteristics of accelerated learners and regular learnes in learning activites. Where, learners are capable of far above this average, usually often seemed relaxed and seemed less attention to the lesson. What is even worse, learners tend to disturb her so that teaching and learning activities in the classroom becomes less smooth. Therefore, to serve the students in learning activities required different curriculum implementation at both learning in order to achieve the expected competencies. This study aimed to describe whether there are significant differences between the grades XI CI + BI learning and learning XI IPA grades in science subjects. This research approach that uses quantitative approaches. While the results of learning outcomes research using quantitative approach that is no significant difference between the grades of accelerated learning $\mathrm{XI}$ CI + BI with grades of regular learning XI IPA in science subjects.
\end{abstract}

Keywords: accelerated learning, regular learning, curriculum implementation

\section{PENDAHULUAN}

Upaya pemerintah untuk memberikan pelayanan pendidikan bagi peserta didik yang memiliki potensi kecerdasan dan bakat istimewa telah dilakukan sejak tahun 1974 dalam bentuk kebijakan atau program.

Berdasarkan hasil penelitian dalam CGIS-Net Assessment System (2008) disebutkan bahwa :

Terdapat 2,2\% anak usia sekolah yang memiliki kualifikasi CI+BI ( Cerdas Istimewa dan/ atau Berbakat Istimewa). Dalam data BPS Tahun 2006 disebutkan terdapat 52.989.800 anak usia sekolah. Artinya, terdapat sekitar 1.059.796 anak usia sekolah yang memiliki kualifikasi CI+BI. Berdasarkan data Asosiasi CI+BI Nasional, baru sekitar 9551 anak CI+BI yang dapat mengikuti program akselerasi. Ditinjau dari segi kelembagaan, dari 260.471 sekolah, baru 311 sekolah yang memiliki program layanan bagi anak CI+BI, sedangkan di madrasah, dari 42.756 madrasah, baru 7 madrasah yang menyelenggarakan program akselerasi. Ini berarti masih sedikit sekolah/madrasah yang memberikan layanan pendidikan kepada peserta didik CI+BI. 


\begin{abstract}
Hasil penelitian tersebut menjelaskan bahwa secara keseluruhan, masih sedikit sekolah yang memberikan pelayanan pada peserta didik yang memiliki potensi dan bakat istimewa. Oleh karena itu, pemerintah mengeluarkan kebijakan tentang pembelajaran akselerasi.
\end{abstract}

Berdasarkan data di lapangan, kurikulum SMAN 1 Padang merupakan kumpulan suatu produk yang dikembangkan di dalam lingkungan sekolah yang berorientasi pada Visi dan Misi sekolah serta tindak lanjut dari Permen 22 tahun 2006 (standar isi), Permen 23 tahun 2006, (Standar Kompentensi Kelulusan), Permen 24 tahun 2006 (pelaksanaan permen 22 dan 23 tahun 2006) dan Permen 41 tahun 2007 (oleh Dinas Pendidikan Kota Padang dan Dinas Pendidikan Pemuda dan Olah Raga Propinsi Sumatera Barat pada awal tahun ajaran 2006/2007 serta berpedoman kepada panduan yang disusun oleh Badan Standar Nasional Pendidikan ( BSNP).

Dalam proses belajar mengajar, guru harus memiliki pedoman atau acuan yang ditetapkan pemerintah dalam menyampaikan suatu materi pelajaran. Untuk itu, guru harus berpedoman pada kurikulum.

Kurikulum yang digunakan pada pembelajaran akselerasi dan pembelajaran reguler pada umumnya sama. Akan tetapi, pada implementasi kurikulum, memiliki perbedaan. Implementasi kurikulum salah satunya dapat dilihat pada proses belajar mengajar. Pembelajaran reguler merupakan suatu program sekolah, yang mana peserta didik menamatkan pendidikannya selama tiga tahun. Pembelajaran reguler dulunya merupakan pembelajaran RSBI.

Berdasarkan hasil pengamatan di sekolah, teridentifikasi beberapa masalah terkait dengan implementasi kurikulum pada pembelajaran akselerasi dan pembelajaran reguler di SMA, yaitu:

1. Dalam pelaksanaannya, guru yang mengajar di kelas akselerasi sama dengan guru yang mengajar di kelas reguler

2. Kurangnya modifikasi model pembelajaran yang diterapkan dalam proses belajar mengajar.

Berdasarkan pada identifikasi masalah, maka di rumuskan masalah pada penelitian ini yaitu apakah terdapat perbedaan implementasi 
kurikulum pada pembelajaran akselerasi dan pembelajaran reguler terhadap hasil belajar peserta didik di Sekolah Menengah Atas?

Metode yang digunakan dalam penelitian ini adalah deskriptif komparatif dengan pendekatan kuantitatif. pendekatan kuantitatif dipakai untuk mendeskripsikan rata rata nilai rapor pada pembelajaran akselerasi dan pembelajaran reguler.

\section{Sumber Data}

Sumber data dalam penelitian ini adalah peserta didik kelas $\mathrm{XI} \mathrm{CI}+\mathrm{BI}$ dan dan XI IPA reguler yang berjumlah 30 orang peserta didik.

\section{Teknik Pengumpulan Data}

Penelitian ini menggunakan teknik Uji $\mathrm{t}$ untuk membandingkan mean dua kelompok data. Uji t dalam penelitian ini merupakan uji $\mathrm{t}$ independen karena data kelompok yang satu tidak tergantung dengan kelompok kedua. Jenis data dalam penelitian ini yaitu data kategorik dan data numerik. Data kategorik berupa nilai dari KKM yaitu $\leq \mathrm{KKM}$ dan $>$ KKM. Sedangkan data numerik berupa nilai rapor XI IPA.

\section{Analisis Data}

Analisis data penelitian kuantitatif untuk nilai rapor peserta didik akselerasi dan peserta didik reguler pada mata pelajaran IPA diolah dengan SPSS 15.0 (Statistical Product And Service Solution).

Pengolahan data menggunakan SPSS 15.0 untuk nilai rapor peserta didik akselerasi dan reguler pada mata pelajaran IPA menggunakan uji t. data yang telah dikelompokkan berdasarkan jenis data yaitu numerik dan kategorik. Setelah data dikelompokkan, maka dilakukan analisis data menggunakan SPSS 15.0.

Bentuk hipotesis alternatif dalam penelitian ini adalah two tail (dua sisi) merupakan hipotesis alternatif yang hanya menyatakan perbedaan tanpa melihat apakah hal satu lebih tinggi/rendah dari hal lain.

\section{HASIL PENELITIAN DAN PEMBAHASAN}

\section{Hasil Penelitian}

Hasil belajar antara peserta didik akselerasi dan peserta didik reguler di SMAN 1 Padang dapat dilihat pada nilai rapor khususnya untuk mata pelajaran IPA (biologi, fisika, kimia, matematika).

Berdasarkan nilai raport peserta didik akselerasi dan reguler didapat data sebagai berikut 
Uji hipotesis untuk mata pelajaran Biologi

Ho: tidak terdapat perbedaan yang signifikan antara nilai rapor pembelajaran kelas $\mathrm{XI} \mathrm{CI}+\mathrm{BI}$ dengan nilai rapor pembelajaran kelas XI IPA pada mata pelajaran Biologi

$\mathrm{H} 1$ : terdapat perbedaan yang signifikan antara nilai rapor pembelajaran kelas $\mathrm{XI} \mathrm{CI}+\mathrm{BI}$ dengan nilai rapor pembelajaran kelas XI IPA pada mata pelajaran Biologi

Berdasarkan hipotesis di atas dilakukan uji $t$ pada nilai rapor pembelajaran kelas $\mathrm{XI} \mathrm{CI}+\mathrm{BI}$ dengan pembelajaran kelas XI IPA pada mata pelajaran Biologi sebagai berikut:

Tabel 1

Nilai Rapor kelas XI CI+BI dan kelas XI IPA Mata Pelajaran Biologi

\begin{tabular}{crrrrr}
\hline $\begin{array}{c}\text { Nilai } \\
\text { Biologi }\end{array}$ & Mean & SD & SE & P value & \multicolumn{1}{l}{ n } \\
\hline$\leq$ KKM & 85,50 & 3,338 & 1,180 & 0,978 & 8 \\
$>$ KKM & 85,45 & 4,032 &, 860 & & 22 \\
\hline
\end{tabular}

Tidak terdapat perbedaan yang signifikan antara nilai rapor pembelajaran kelas XI CI+BI dengan nilai rapor pembelajaran kelas XI IPA pada mata pelajaran Biologi.

Uji hipotesis untuk mata pelajaran Fisika

$\mathrm{H} 0 \quad$ : tidak terdapat perbedaan yang signifikan antara nilai rapor pembelajaran kelas $\mathrm{XI} \mathrm{CI}+\mathrm{BI}$ dengan nilai rapor pembelajaran kelas XI IPA pada mata pelajaran Fisika
$\mathrm{H} 1$ :terdapat perbedaan yang signifikan antara nilai rapor pembelajaran kelas $\mathrm{XI} \mathrm{CI}+\mathrm{BI}$ dengan nilai rapor pembelajaran kelas XI IPA pada mata pelajaran Fisika

Berdasarkan hipotesis di atas dilakukan uji $t$ pada nilai rapor pembelajaran kelas $\mathrm{XI} \mathrm{CI}+\mathrm{BI}$ dengan pembelajaran kelas XI IPA pada mata pelajaran Fisika sebagai berikut :

Tabel 2

Nilai Rapor kelas XI CI+BI dan kelas XI IPA Mata Pelajaran Fisika

\begin{tabular}{crrrrr}
\hline $\begin{array}{c}\text { Nilai } \\
\text { Fisika }\end{array}$ & Mean & SD & SE & P value & N \\
\hline$\leq$ KKM & 87,43 & 3,777 & 1,009 & 0,242 & 14 \\
$>$ KKM & 89,00 & 3,425 & 0,856 & & 16 \\
\hline
\end{tabular}


Tidak terdapat perbedaan yang signifikan antara nilai rapor pembelajaran kelas $\mathrm{XI} \mathrm{CI}+\mathrm{BI}$ dengan nilai rapor pembelajaran kelas XI IPA pada mata pelajaran Fisika.

Uji hipotesis untuk mata pelajaran Kimia

$\mathrm{H} 0 \quad$ : tidak terdapat perbedaan yang signifikan antara nilai rapor pembelajaran kelas $\mathrm{XI} \mathrm{CI}+\mathrm{BI}$ dengan nilai rapor pembelajaran kelas XI IPA pada mata pelajaran Kimia
H1 : terdapat perbedaan yang signifikan antara nilai rapor pembelajaran kelas $\mathrm{XI} \mathrm{CI}+\mathrm{BI}$ dengan nilai rapor pembelajaran kelas XI IPA pada mata pelajaran Kimia

Berdasarkan hipotesis di atas dilakukan uji $t$ pada nilai rapor pembelajaran kelas $\mathrm{XI} \mathrm{CI}+\mathrm{BI}$ dengan pembelajaran kelas XI IPA pada mata pelajaran Kimia sebagai berikut :

Tabel 3

Nilai Rapor kelas XI CI+BI dan kelas XI IPA Mata Pelajaran Kimia

\begin{tabular}{crrrrr}
\hline $\begin{array}{c}\text { Nilai } \\
\text { Kimia }\end{array}$ & Mean & SD & SE & P value & n \\
\hline$\leq \mathrm{KKM}$ & 83,43 & 3,359 & 1,270 & 0,484 & 7 \\
$>\mathrm{KKM}$ & 82,48 & 3,028 & 0,631 & & 23 \\
\hline
\end{tabular}

Tidak terdapat perbedaan yang signifikan antara nilai rapor pembelajaran kelas XI CI+BI dengan nilai rapor pembelajaran kelas XI IPA pada mata pelajaran Kimia.

Uji hipotesis untuk mata pelajaran Matematika

Ho : tidak terdapat perbedaan yang signifikan antara nilai rapor pembelajaran kelas $\mathrm{XI} \mathrm{CI}+\mathrm{BI}$ dengan nilai rapor pembelajaran kelas XI IPA pada mata pelajaran Matematika
H1 : terdapat perbedaan yang signifikan antara nilai rapor pembelajaran kelas $\mathrm{XI} \mathrm{CI}+\mathrm{BI}$ dengan nilai rapor pembelajaran kelas XI IPA pada mata pelajaran Matematika

Berdasarkan hipotesis di atas dilakukan uji $t$ pada nilai rapor pembelajaran kelas $\mathrm{XI} \mathrm{CI}+\mathrm{BI}$ dengan pembelajaran kelas XI IPA pada mata pelajaran Matematika sebagai berikut: 
Tabel 4

Nilai Rapor kelas XI CI+BI dan kelas XI IPA

\begin{tabular}{crrrrr}
\multicolumn{8}{c}{ Mata Pelajaran Matematika } & & \\
\hline $\begin{array}{c}\text { Nilai } \\
\text { Matematika }\end{array}$ & Mean & \multicolumn{1}{c}{ SD } & SE & P value & \multicolumn{1}{c}{ n } \\
\hline$\leq$ KKM & 87,42 & 5,035 & 1,454 & 0,414 & 12 \\
$>$ KKM & 82,28 & 20,956 & 4,939 & & 18 \\
\hline
\end{tabular}

Tidak terdapat perbedaan yang signifikan antara nilai rapor pembelajaran kelas XI CI+BI dengan nilai rapor pembelajaran kelas XI IPA pada mata pelajaran Matematika.

\section{Pembahasan}

Hasil belajar merupakan hal yang dapat dipandang dari dua sisi yaitu sisi peserta didik dan dari sisi guru. Dari sisi peserta didik, hasil belajar merupakan tingkat perkembangan mental yang lebih baik bila dibandingkan pada saat sebelum belajar. Sedangkan dari sisi guru, hasil belajar merupakan saat terselesaikannya materi pelajaran.

Hasil belajar peserta didik akselerasi dan peserta didik reguler yang diperoleh diukur berdasarkan perbedaan tingkah laku sebelum dan sesudah belajar dilakukan. Salah satu indikator terjadi perubahan dalam diri peserta didik sebagai hasil belajar di sekolah dapat dilihat melalui nilai yang diperoleh peserta didik di akhir semester.
Tujuan kegiatan belajar mengajar adalah perubahan tingkah laku, baik yang menyangkut pengetahuan, keterampilan, dan sikap. Kegiatan belajar mengajar seperti mengorganisasi pengalaman belajar, menilai proses dan hasil belajar, termasuk dalam cakupan tanggung jawab guru dalam pencapaian hasil belajar.

\section{KESIMPULAN}

Berdasarkan hasil penelitian yang telah dilakukan, maka dapat disimpulkan bahwa studi komparasi pembelajaran akselerasi dengan pembelajaran reguler memiliki persamaan dan perbedaan. Persamaan antara pembelajaran akselerasi dengan pembelajaran reguler terletak pada laporan hasil belajar atau rapor untuk peserta didik akselerasi sama dengan peserta didik reguler.

Adapun perbedaan antara pembelajaran akselerasi dengan pembelajaran reguler adalah dalam hal hasil belajar peserta didik kelas XI 
$\mathrm{CI}+\mathrm{BI}$ dan peserta didik kelas XI IPA khususnya pada mata pelajaran IPA.

Proses pembelajaran yang terjadi di pembelajaran akselerasi maupun pembelajaran reguler diharapkan mampu menjunjung tinggi keaktifan peserta didik yang tidak hanya melibatkan otak, hati, dan tangan, melainkan keseluruhan kemampuan yang dimiliki seorang manusia yaitu berhubungan dengan pikiran, moral, sosial, dan belajar secara komprehensif.

\section{DAFTAR PUSTAKA}

Ahmadi, Iif Khooiru, dkk. (2011). Pembelajaran Akselerasi Analisis Teori dan Praktek Serta Pengaruhnya Terhadap Mekanisme Pembelajaran dalam Kelas Akselerasi. Jakarta: Prestasi Pustaka

Akbar,Reni dan Hawadi. (2006). Akselerasi Program Percepatan Belajar dan Anak Berbakat Intelektual. Jakarta: Grasindo

Arifin, Zaenal. (2009). Evaluasi Pembelajaran. Bandung: Remaja Rosdakarya

CGIS-Net Assessment System (2008) dalam kumpulan makalah Konferensi Nasional ke-1 Pengembangan pendidikan Khusus untuk peserta didik Cerdas/Berbakat Istimewa, Malang, 5-8 Februari 2010).
Dokumen 1 Kurikulum SMA Negeri 1 Padang Tahun Ajaran 2012/ 2013

Emzir. (2010). Metodologi Penelitian Pendidikan Kuantitatif dan Kualitatif. Jakarta: Rajawali Press

Hastono, Priyo Sutanto. (2006). Basic Data Analysis for Health Research Training. Depok: Fakultas Kesehatan Masyarakat Universitas Indonesia

Rusman.(2008). Manajemen Kurikulum Seri Manajemen Sekolah Bermutu. Bandung: Mulia Mandiri Press

Sanjaya, Wina.(2008). Kurikulum dan Pembelajaran Teori dan Praktik Pengembangan KTSP. Jakarta: Kencana Prenada Media Grup

Sukmadinata. (2008). Metode Penelitian Pendidikan. Bandung: PT Remaja Rosdakarya

Tim Pengembang MKDP Kurikulum dan Pembelajaran. (2009). Kurikulum dan Pembelajaran. Bandung: Jurusan Kurikulum Teknologi Pendidikan FIP UPI

Winkel. (1987). Psikologi Pengajaran. Jakarta: PT. Grafindo 